HStud 23 (2009)1, 77-105

DOI: 10.1556/HStud.23.2009.1.7

\title{
EXILE IN THE HOTEL PLAZA: THE TWILIGHT YEARS OF FERENC MOLNÁR (1940-1952)
}

\author{
ÁGNES SZÉCHENYI \\ Institute of Literary Studies, HAS, Budapest \\ Hungary
}

\begin{abstract}
The internationally recognized Hungarian playwright Ferenc Molnár settled over to the United States in 1940, well beyond the top of his career. He was an essentially Hungarian, more precisely metropolitan author, with accents from Pest, famour for his ingeniously Hungarian sense of humour. Yet he became the most frequently translated Hungarian playwright of his era, with immense and immediate international success. Practically, Molnár did not live in Hungary from the beginning of the Horthy era (1920-1944), but the Jewish-Hungarian author decided to leave Europe well after Hitler's takeover only. His name was known even in the United States: his first really successful play, The Devil was staged in New York in 1908, a year after being first performed in Budapest. Several of his plays had a phenomenal success story in the 1920s, his The Play is the Thing had its world premiere in New York in 1926. Carousel, the "Best Musical of the 20th Century", by Rodgers and Hammerstein, was based on Molnár's 1909 play Liliom.

This article aims at reconstructing Molnár's overseas network and recreating the spirit and growing loneliness of immigrants. It also tries to answer the question of how the work of an author so deeply embedded in Hungarian language and culture could be translated and adapted to foreign languages.
\end{abstract}

Keywords: Jewish-Hungarian culture, international success, Max Reinhardt, Broadway, emigration, exile, Paul Street Boys, Carousel, adaptation of genre conventions, immigrant spirit

The Hungarian author Ferenc Molnár ${ }^{1}$ (1878-1952) arrived in New York on board the Italian ocean liner Rex on January 12, 1940, on his 62nd birthday, as it so happens. By that time he was already a world-famous playwright. His plays, especially The Devil, The Guardsman, Liliom, and The Play is the Thing, had been performed all over the world with great success; his stagecraft served as the pattern of dramaturgy. A very young Ingrid Bergman, personally unknown to Molnár at the time, was also a passenger aboard the Rex. She would later play in the New York revivals of Liliom to great acclaim. The Rex sailed on New Year's Eve and the passage took twelve days. The quotation below is from Molnár's 
autobiography Companion in Exile (1950). The curiosity of this autobiography lies in the fact that about one third of the book was copied by Molnár from his secretary's diary. She had worked for Molnár for fifteen years and had kept a diary about their life together.

\begin{abstract}
When their vessel finally came alongside the pier in the dark winter night, the cheers from ashore could be heard on shipboard, followed by a singing chorus. M. was surprised: he supposed that either the Hungarian colony or his friend Gilbert Miller, ${ }^{2}$ who had produced a lot of his plays in New York, had arranged it. Now M. says it is possible that Miss Bergman also thought the ovation was for her, because she was a famous Swedish actress, and a Hollywood picture of hers, Intermezzo (with Leslie Howard), was running successfully in New York. Even before they went ashore, M. discovered that the jubilant ovation and the chorus of hundreds of voices were a Zionist welcome intended for Dr. Chaim Weizmann, ${ }^{3}$ the leading champion of the Jewish homeland in Palestine, who arrived on board the same ship, unknown to either M. or Miss Bergman. Despite his esteem for Dr.Weizmann, M. said it was quite an anti-climax to walk down the gangplank to the sounds of the chorus. The voyage was not at all bad, M. said, aside from the uneasy feeling caused by the whispering about a British destroyer that accompanied the vessel at a respectful distance in case of German submarines, to guard one passenger, a certain Mr. Butler, one of the highest officials of the British Embassy in Washington."
\end{abstract}

This passage makes mention of the different social layers of the illustrious passengers on board the Rex, which functioned as a sort of Noah's ark between the continent and the United States for people fleeing from Nazi Europe: there was the writer, the actress, the politician, and the diplomat. When Molnár later read in the newspapers that the Rex had been sunk during the war, he offered the following remark: "Poor Rex has had a bad end, but she brought luck to some of my fellow passengers. The slow-rising and very different careers of passengers Michael Todd, ${ }^{5}$ Ingrid Bergman, and Chaim Weizmann skyrocketed soon after landing."6 It seems that the Hungarian writer did not include himself among those to whom America had brought luck. The reason was that by the time he arrived in the United States, his career had already passed its height. His fame was kept alive mainly by his successful plays, staged in long-running series. During his years of exile he did not write any works of outstanding merit, and most certainly none of the kind that would have become part of the international canon.

He did, however, write one important historical drama, The Emperor, in 1942. It is a surprising play because it is a tragedy, and Molnár was well known as a comedy writer. The play was conceived at the encouragement of his Austrian friend, Max Reinhardt, ${ }^{7}$ the great European stage innovator who was also living in 
America at the time. The goal of Reinhardt must have been to urge Molnár to write again, since having left Europe Molnár had lost his balance. (Reinhardt would have liked to play the role of the main character, but he died in 1943.) Presumably, Molnár intended to reenter the theatrical life of Budapest with this play. The Emperor is a tragedy about a theater company set in the Napoleonic era. Indirectly, it confronts the issues of dictatorship, war and the distinction between real and feigned emotions. ${ }^{8}$ In fact, the play was put on stage only in Budapest, and for half a season and it did not have much success. The Hungarian audience had expected Molnár to provide what it had been accustomed to: light, attention-diverting entertainment. The comeback was not a success.

\section{Budapest: The Beginnings of a Career}

Molnár was born in Budapest in 1878. His career developed along with the city where he was rooted. The united capital of Budapest had been established only five years before his birth. Previously it had consisted of three historically, culturally, and ideologically different cities, Pest, Buda, and Óbuda. ${ }^{9}$ Up to that time, the national literature had been more rural in its orientation and world view. ${ }^{10}$ Molnár used to refer to his birthplace as "my native village, Pest". The city was bilingual, with the Hungarian bourgeoisie speaking German and Hungarian. This was the era of the Austro-Hungarian Monarchy. Pest radiated a special ideological atmosphere: the heritage of the Revolution of 1848 was still palpable and the atmosphere was enriched by liberalism and the urban impulses. After the 1873 unification of Pest, Buda and Óbuda, the capital underwent enormous development. With its 733,000 inhabitants it had become the eighth largest European city by the turn of the century. ${ }^{11}$ Within the capital alone, forty-eight daily newspapers were published, more than in any other European city. In addition to the thirtynine Hungarian language newspapers there were also nine German papers. The entire output of the Hungarian news publications reached 154,000,000 copies per year. This was a historical turning point in the intellectual life of Hungarians. 1882 marked a symbolic moment in Hungarian literature as the year in which János Arany died. He had been an outstanding, celebrated, and yet soft-spoken literary figure. He represented the combination of two worlds: the rural literary world and the Revolution of 1848 on the one hand and the world of the swiftly developing capital on the other. The older generation was frightened by these swift changes. It was at this moment that a new generation entered the scene. This latter, urban world was Molnár's natural habitat.

Molnár was an urban character. He came from an upper middle-class Jewish family; his father was a well-known surgeon in Budapest. The social network and the high esteem surrounding the family were shown by the fact that Molnár's fa- 
ther, Dr. Neumann, was the company physician at the world-famous Ganz Works. He also treated the French architect Gustav Eiffel, who maintained an office in Budapest for some years. (Gustav Eiffel's design office built two landmarks which still define Budapest: the Western Railroad Station and Margaret Bridge.) Max Nordau, the doctor, Austro-Hungarian writer and editor who later became one of the leaders of the Zionist movement, was also among his father's close friends. ${ }^{12}$ At the end of the 19 th century it was quite natural for the family to send the son to pursue his studies abroad, in this case to Geneva, where Molnár studied law. Molnár regularly made excursions to Paris and saw everything that was worth seeing in the theatres. Up until the outbreak of the First World War anyone whose social status and financial conditions permitted it could move about freely and live anywhere in Europe without a passport. ${ }^{13}$ Molnár Hungarianized his name in 1896, the year of the Millennium, and thus Ferenc Neumann turned into Ferenc Molnár. This was the era of the relatively tolerant, liberal Hungary of the period following the Compromise of 1867 and before the outbreak of the First World War. As an immediate consequence of defeat in the war, two left-wing revolutions took place in 1918 and 1919, followed by the Trianon Peace Treaty of 1920, which remains one of the greatest calamities in Hungarian historiography. Hungary lost rougly two-thirds of its territory and fifty percent of its population. The decades between 1867 and 1914 are known as the Happy Times of Peace in Hungarian history. They were followed by a drastic transformation characterized by the hunt for scapegoats, in this case the Jewish intellectuals and revolutionary leaders. It was this atmosphere that brought about the passage of the first numerus clausus law in Europe in 1921. ${ }^{14}$ Many of Molnár's friends were gravely affected by this atmosphere, and he himself was not unscathed. All this, however, took place primarily in Budapest, and the population and culture of the capital bore much of the blame for the disastrous state of affairs.

Both as a journalist and as a writer, Molnár dealt with the theme of the growing and changing city of Budapest. He wrote an article about what Budapest was like in 1911entitled The Hungarian Budapest, in which he takes a resolute stance against accusations that the capital is not genuinely Hungarian in its culture. Molnár writes that the capital is referred to metaphorically as "a helpless, poor Jew" standing in the middle of a huge map of Hungary. He does not share this view. It is "her enemies who picture and make her as such. Her enemies say she is American, international, non-patriotic, un-Hungarian, riff-raff, she has nothing to do with Hungarians, and she does not deserve the appellation 'heart of the country"'. In Molnár's view, if a city "enters the international association of capitals then it is supposed to live according to an unwritten line of ceremonies present in the common knowledge of the world; it has to take up ten thousand new customs and habits taken up by every capital; it has to build a Stock Exchange, it has to run electric trams, and so on and so forth; and through all this, it has to assume a capi- 
tal-like appearance, which directly contradicts the atmosphere of a village or a small town, mistaken by these gentlemen for a national and racial atmosphere". It is important to remark that the phenomenon described by the writer was by no means exclusively Hungarian: many large European cities and capitals were subjected to similar criticism at the time.

The literature on Molnár has not yet taken into consideration the character of the circle of friends, writers and journalists who surrounded and influenced him in the early years of his career. It is revealing to consider his place in the circle of journalists with whom he started to work at the urban literary journal $A$ Hét (The Week) and the daily paper Budapesti Napló (Budapest Diary). As the first journal of its kind in the capital, $A$ Hét was the engine driving the modernization of literary life. If we examine the liberal spirit of these editorial offices at the turn of the century, it is easier to understand why Molnár felt much more at home in Western Europe after 1920, when the Austro-Hungarian Monarchy had collapsed and the liberal spirit of intellectual and political life had disappeared from Hungary, practically from one day to the next.

The leader of the Budapesti Napló was József Vészi, ${ }^{15}$ a liberal journalist who a decade later, as it so happens, became Molnár's father-in-law. ${ }^{16}$ Oszkár Jászi, forced into permanent exile in 1919, also began his career at this daily. In a supplement, Jászi acquainted the Hungarian readership with the discipline of sociology. ${ }^{17}$ Lajos Biró, Molnár's future brother-in-law, also worked there. In the bourgeois democratic Károlyi cabinet of $1918,{ }^{18}$ Biró (along with Jászi) became a state secretary in charge of nationality issues. From the turn of the century he had predicted that disregard for the rights of nationalities could be one of the breaking points of the Monarchy. He had been proven right in the weeks following the end of the First World War. Like Jászi, both Károlyi and Biró were forced to emigrate in 1918-1919. József Vészi, Molnár's ex-father-in-law, remained the leader of the consistently pro-government Pester Lloyd. The one-time admirer of the artistic and political radicalism of the turn of the century slowly came to accommodate (like so many others who remained in the country) the prevailing conservative views of the Horthy Era.

Under Vészi's editorship, the Budapesti Napló played a significant role not only in politics but in literature, too. At the end of the 19th century and at the beginning of the 20th literature and journalism were not yet entirely separate. Perhaps the greatest merit of Vészi's work was that at the turn of the century and over next few years he managed to gather together the most talented writers of the era, the youngest of whom were to make their careers in the inter-war period. We need mention only the most outstanding talents, the revolutionaries of the first decades: Endre Ady, Dezső Kosztolányi, Lajos Biró, and Géza Csáth. Dailies were natural forums for literature, and they particularly favored the genre of the feuilleton. 
Apart from Molnár's writings and short stories published in dailies, he polished the technique of his stage dialogues in his crime reports, sketches, glossaries, and articles. In the tableaux of a number of his works the background settings of certain scenes can be found in the "graveyard" of the once popular dailies. Molnár did not employ journalistic commonplaces. Nor are his writings, although published anonymously, difficult to identify, for his interests, views, and turning-points distinguish him clearly from the work of his colleagues. He had already become an internationally renowned playwright, with an omnibus volume ${ }^{19}$ published simultaneously in Hungarian, English, German and Italian in Rome, when he professed that he considered himself first and foremost a journalist who "would never be anything else". During his first American tour he describes his profession like this:

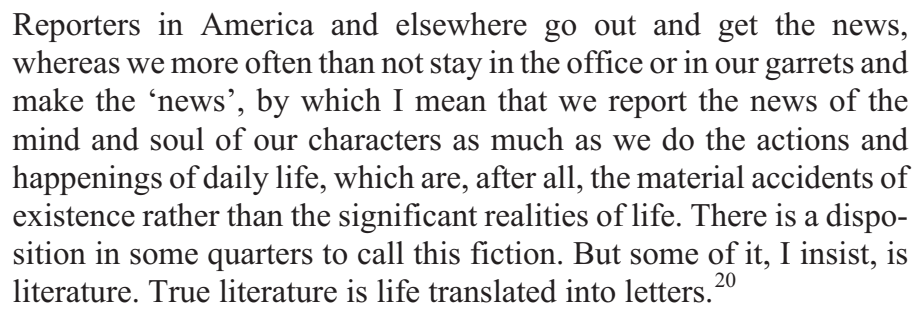

Molnár turned a court trial into a short story in the news section. He became popular with croquis wittily making fun of the oddities of life in Pest and with chronicles that offer clever analysis of social issues. Interestingly, in 1898, as a mere twenty-year-old tenderfoot journalist, Molnár interviewed Ermete Zacconi, ${ }^{21}$ the traveling prince of the Italian theater who in 1908 would catapult The Devil and its author into world fame.

At the beginning of The Devil's continental popularity, Molnár remarked once that when the play was staged three gestures had been modified or deleted by directors in the theaters of different European countries on the grounds that a Berlin painter would never make a comment like the one given him, a Viennese lady would never act in the way she is depicted as acting, and a London gentleman would never don the garb called for by the script. He wrote,

By the end of an international play, this is how I turned into [...] an author of intolerably Hungarian national character. This made me think: these are just small examples, but you see, they are still the result of my being Hungarian, my being born of this land, my being brought up here; these small things go unnoticed at home, but abroad my play is censored[.] $]^{22}$

This gesture of self-characterization is significant. The author labels his play international. Indeed it was, even in terms of its genre, since it built on situation 
comedy. What is little known about Molnár is that at the beginning of his long career he also worked as a translator. He translated twenty-nine French works for the theater into Hungarian, including some serious dramas, but mostly operettas and farces. ${ }^{23}$ His role, however, was not confined to that of the translator. He not only Hungarianized the plays, but also rewrote them, creating better psychological bases for the turning-points and making the dialogues more life-like and easier to perform. He knew various contemporary French authors personally. Translation served as a training school; he became skilled in successful clichés. Molnár did a remarkably good job, and drama critics even referred to him as a co-author. As a witty Hungarian theater expert commented, Molnár "learned his own style from foreigners". ${ }^{24}$ In The Play Is the Thing the author's double actually confesses how many ideas and solutions he has stolen from the French.

By the time his first play was performed for the public, he was a fully-fledged playwright. His first longer play, The Doctor, was immediately well-received, and was quickly followed by three plays that led to world fame: The Devil (1908), ${ }^{25}$ Liliom (1909), ${ }^{26}$ and The Guardsman (1910).

\section{The Author of "Export Dramas"}

Molnár's popularity abroad did not win him immediate acceptance at home, however. A still highly esteemed volume, first published in $1934,{ }^{27}$ offering an overview of the history of Hungarian literature relegated Molnár, who enjoyed world fame at the time, to the short chapter bearing the title "export-dramas". What does this category mean? Does it entail a value judgment or is it a simple statement referring to the fact that the author's plays would live up to the expectations of any audience in the world? Hungarian literature is an East Central European literature tightly confined within its idiom. The historical development of the country gave rise to a largely moral imperative: namely, that a Hungarian writer's role is to address the vitally important matters of the nation, i.e., to present unsolved social problems and elevate them into the sphere of literature, while at the same time calling them to the attention of the political sphere. ${ }^{28}$ Though he was an excellent writer of prose, Molnár became world famous as a playwright. Yet his works as a playwright seemingly do not fit the above expectations at all, since he used a light tone even when voicing social criticism (though mostly at the beginning of his career and in his prose works). ${ }^{29}$ However, one of his first novels, The Paul Street Boys ${ }^{30}$ published in 1907, remains an emblematic Hungarian literary example of self-sacrificing patriotism. It constitutes one of the shared elements of Hungarian cultural national consciousness. Another masterpiece is a short novel from 1926 entitled The Captain of St. Margaret's, where by offering a digressive 
narrative of the life story of a romantic personality he widens the borderlines of prose writing and creates a new form of poetry. ${ }^{31}$

As far as the original meaning of "export" is concerned, however, it is true of Molnár in every sense. He was not merely an exportable author of Hungarian literature: he was the very first author of Hungarian literature who entered the wider world with such an overwhelming, loud, and intercontinental success. ${ }^{32}$ At the age of 30 Molnár made his foreign debut with The Devil, which premiered in New York only one year after opening in Budapest. The Devil was the foundation of Molnár's fame in Europe and overseas. After its premiere in Budapest, it was soon produced in Turin, Berlin, Warsaw, London and Vienna. ${ }^{33}$ In New York it was put on by David Belasco, the most prominent and influential personality of the theatrical world of the era, at his Stuyvesant Theater on Broadway. At the time, the Stuyvesant was perhaps the most modern theater in the city, equipped with hydraulics and special lighting technology making use of Tiffany lamps. ${ }^{34}$

According to the bibliography on Molnár, ${ }^{35}$ the Garden Theater ${ }^{36}$ also produced the play in the very same season. In the monograph written by Molnár's grandson in the style of a long essay based on anecdotes (and lacking any references), ${ }^{37}$ two additional theaters ran the play in New York at the same time, one in German and another one in Yiddish. The bibliography contains the full list of New York and U.S. premieres, but a few details are worth mentioning in this context. By the time Molnár finally settled down in New York, he had had no less than twenty-nine theater premieres. Moreover, seventeen movies were made from his works in America ${ }^{38}$ To this impressive presence in American cultural life we can add that soon after his fiftieth birthday a collection of his dramas was published in English in the U.S. A decade later this edition was followed by a deluxe edition. ${ }^{39}$ Both editions included David Belasco's foreword and a literary portrait of Molnár by his English translator, Louis Rittenberg. ${ }^{40}$

As a result of his growing prominence in American theatrical life the many successes of his plays, Vanity Fair and many other American papers with large circulations published articles on his work and interviews with him. The popularity of his plays brought him continuous publicity. Molnár's frequent statements were light-hearted; he knew what editors, readers and theater-goers were interested in. Having been a journalist himself, he must have been aware of the fact that his colleagues utilized manipulative techniques all over the world. As the letters he sent to his wife reveal, he sometimes consciously made use of publicity, while at other times he kept his distance from the limelight. (Molnár's prose works are full of data regarding his ideas concerning the functions, technique and morality of the press of his age.) The turn of the century and the decade after it were the time of the birth of mass communication and mass culture in Hungary, and Molnár himself was one of its creators. Another phenomenon that went hand in hand with these changes was the development of the role of advertising. ${ }^{41}$ Very early in this 
process Molnár's "mother theater," the Vígszínház [Merry Theater] in Budapest, advertised and popularized their programs internationally. ${ }^{42}$ Moreover, something that was uncommon in Hungary at the time was the presence of professional agents and modern businessmen involved in publishing around the exportable writers and playwrights. ${ }^{43}$

\section{First Time in America}

In 1940, when Molnár set foot on Ellis Island as an immigrant to the United States, he was already somewhat familiar with New York City. In late 1927 he had visited the country as a guest. He held a lecture on Hungarian drama at Columbia University ${ }^{44}$ and appeared at a cocktail party given in his honor by the editorial office of Vanity Fair, where Ina Clair and Leslie Howard read from his writings published in the magazine. ${ }^{45}$ In the company of Hungarian Ambassador Count László Széchenyi and producer Gilbert Miller, Molnár was also received by the President of the United States, Calvin Coolidge. ${ }^{46}$ During his stay he got to know George Gershwin, who asked him for permission to set his play Liliom to music. Molnár did not grant the rights to Gershwin at the time, though he held Gershwin in high esteem and kept the autographed photograph he received from the composer on the occasion on his desk. Earlier there had also been plans for Puccini to write an opera based on Liliom. Various articles gave news about the issue in 1922, and there are documents proving that Puccini was considering the opportunity, but he was much too busy with Turandot at the time. As historian of American drama Roy S. Waldau notes,

There had [also] been a discussion of turning Liliom into a musical play with Kurt Weil to write the music and Arthur Guiterman the lyrics. But, when inquiries were made, Ferenc Molnár's agent informed the managers that the Hungarian author showed no enthusiasm whatsoever for sanctioning a musical version of his script as proposed by the organization. ${ }^{47}$

There is no information available concerning who initiated Molnár's trip to New York in 1927. It is suspected that he adjusted his trip around the visit to the city made by the theater company of Lili Darvas and Max Reinhardt. Molnár spent a shorter period of time there than the company. He arrived later and returned to Europe earlier than his wife. He was well-known in America and was celebrated as a star author immediately upon arrival. According to some of the biographies (which are based on sources impossible to check), he was nominated for a Nobel Prize in literature in the fall of $1926 .{ }^{48}$ In 1927 he received the French Légion d'Honneur, and word had it that over the course of the 1920s he made over 
one-million dollars, though no data are available to confirms this. If indeed this was the case, the source of his wealth may well have been the success of editions of his plays published in translation abroad and the popularity of life performances of his plays. Liliom was performed 285 times in 1921 and The Swan 255 times in 1923. This was followed by the influence of silent films and later talkies. Even before his first visit to America, the world premiere of The Play Is the Thing was held in New York in 1926. The Budapest premiere took place only three-and-a-half weeks later. The Play Is the Thing, translated by P.G. Wodehouse, was performed 326 times. The script was translated from German and, like Molnár's translations from French, was not faithful to the original. ${ }^{49}$ It was Henry Miller, ${ }^{50}$ actor and theater founder, and his son, Gilbert Miller, influential Broadway and the West End producer, who upon reading the German translation believed so strongly in the success of the play that he immediately resolved to translate and produce it. In the case of The Play Is the Thing this was more an adaptation than translation in the strict sense.

\section{A Small Language and World Literature}

One might well raise the question as to how a small country with a distinctive language little known outside the region can enter world literature. Molnár's career seems to support the idea that small nations can influence the canon through the interference of cultural impact and the plasticity of genre conventions. ${ }^{51}$ One might add that themes have to be built around general parables or symbols, not incidental aspects of national culture, so that the basic theme can be formed freely. ${ }^{52}$ Molnár play constitutes an example of such a work.

Upon returning home from his first trip to America, Molnár wrote a one-act play entitled One, Two, Three in 1929. ${ }^{53}$ In this play, America appears indirectly. It is about the apple of the eye of one of the wealthiest and most distinguished families of America, who gets to spend a few months with the family of a European banker. Just before her parents' arrival, the American girl confesses to her host (who is hoping to strike a profitable deal involving American cars) that she has not only married a taxi driver, but she is also pregnant with his baby. The parents are due to arrive in an hour, and the banker has to prevent a scandal. In the short time available to him, the banker turns the unpolished boy into a conservative young man of high rank, even going so far as to purchase him a noble title. Money is omnipotent; the banker's machine works according to orders. The play, of course, has a happy ending, and essentially equates illusion and reality. There is little information concerning the conception of the play, but supposedly it includes many of the author's experiences of his overseas visit. America means business, the op- 
portunity to make good deals, and progress. The play lasts roughly one hour, during which time it is mostly the banker who speaks, giving orders to his employees with telegrams. America receives a strange rebuff from Molnár in the play. $\mathrm{He}$ considers America the central motivating power of business and the central point of the desires of the Europeans, but he sees the falsity of its world. The America theme had appeared in Molnár's oeuvre before this play, and not only in his writings. At the turn of the century, in the midst of the emigration fever, both public and literary attention were increasingly drawn to the continent that allegedly promised career opportunities and a high standard of living. This theme appeared in many short stories, novels, and travel accounts by various Hungarian literary authors. ${ }^{54}$ The subject figures early in the oeuvre of Molnár as well, specifically in his first novel, The Hungry City, written in 1901. Lacking personal experience, he presents the stereotypical image of immense wealth alongside a depiction of the sober, honest American mentality. This novel suddenly put him in the center of attention of Hungarian literary consciousness, although it was in fact little more than a pamphlet-like inventory of urban perversities and gossip, as noted by critic Aladár Schöpflin, also a spokesman of the program of urbanization. ${ }^{55}$ The shortcoming of the novel is that its characters are sufficiently vivid and function as transparent mouthpieces for the views of Molnár the journalist himself.

From the mid-1920s, Molnár lived abroad almost continuously in the elegant hotels of Europe. A well-known bon mot preserved his philosophy of life, namely, that in fact he was the owner of a five-room apartment with one room in the Hotel Hungária in Budapest, another room in the Imperial in Vienna, another in the Carlton in Cannes, another in the Eden in Berlin, and another in the Danieli in Venice. Following the rise of Hitler, he used his room in Berlin less and less frequently. Once the Germans had annexed Austria in 1938, he had to give up another room, and eventually all of them.

Molnár was proficient in German and French, and spoke Italian fairly well, thus he did not face linguistic barriers on the continent. The knowledge of languages is a prerequisite of cultural openness and freedom. At the turn of the century Budapest was bilingual, in particular the assimilating Hungarian Jewish community from which Molnár originated. His command of English, however, never reached a level that would have enabled him to communicate freely in it as if it were "his own" language.

At first he was able to travel because of the status of his family, and later he had to travel because of the productions of his plays abroad. Molnár appeared in front of the European public not only as a playwright. His successes made him extremely popular, and the public was interested in his writings in other genres as well. In the thirties, for example, the Berliner Tageblatt published a series of his feuilletons every other week. ${ }^{56}$ 


\section{Ferenc Molnár's Uneasy Private Life}

There is a third reason underlying Molnár's absence from home. His third wife, Lili Darvas, twenty-four years younger than he, did not live with him. The actress, who was very young when she flashed like a shooting star through the theatrical life of Budapest, did not give up her career for her husband's sake. In the opinion of theater historians, she had obvious reservations about the gossip and critics of the theater life of Budapest. She did not consider the reviews honest, and she thought she was treated as an actress who belonged to Molnár. This contributed to her decision to leave Hungary. She began her highly successful German language career at Max Reinhardt's theater in Vienna in 1925, at the time of her wedding. She did much of her acting in Vienna and Berlin, and practically lived in those cities. As early as the first year of her association with the theater, Max Reinhardt wanted to take her to America for a guest performance. Molnár, however, did not agree, and shortly after the wedding the husband's word carried more weight. Although Molnár supported his wife's professional career, it was difficult for him to tolerate her absence. He wrote about this in his memoirs as follows: "My wife's brilliant stage career, tying her to Berlin and Vienna, kept her almost constantly thousands of miles away from me. My only chance of spiritual survival was to roam the Latin west." 57

It was common knowledge that Molnár treated women roughly. He had violent arguments with his first two wives. ${ }^{58}$ He never lived under the same roof as Darvas, but they stayed close to each other whenever possible, and they carried on a very intense correspondence throughout the thirties. Upon reading what has remained of their letters, one gets the impression that it was rather the wife who preferred to keep her distance. Eventually, they ended up living in New York just a few streets apart, and his wife's opinion always remained very important to him. Living separately, however, resulted in Molnár practically living together with another young woman from 1932 on, the devoted and naive Wanda Bartha, who looked up to Molnár like a god and officially acted as his secretary. The literature on Molnár discreetly avoids specifying the woman's relationship with the author. ${ }^{59}$ The fact remains that they traveled around the most beautiful regions of Europe together. As Molnár commented: "We were a lonely, taciturn, wandering couple in trains, hotels, bistros, and sidewalk cafés. ${ }^{, 60}$ Darvas tolerated the situation. Molnár needed a secretary, but as the letters reveal, it was his wife and his wife's independence and strength of character that had a great impression on him.

One touching aspect of Molnár's letters from the thirties is the way in which he took care of his wife. For example, when she had to travel he summarized the things that needed to be tended to beforehand in a colorful table for her. He outlined the procedure for obtaining a visa and purchasing tickets, and even gave advice on which carriage in which to travel. He also thought of contacting a few lo- 
cal people to whom Darvas could turn in case of trouble. At the end of the thirties, immediately following the outbreak of the Second World War, when it became more difficult to send letters, he asked her not to write in Hungarian so that the letters could go through censorship more quickly and he would receive them sooner. Through his connections back home, he secured his wife's papers and asked for her citizenship certificate. Molnár deposited the documents he obtained in safe custody so that she would be able to access them whenever necessary. He arranged to have a monthly allowance of 2,500 dollars transferred to her, and in addition also authorized her to draw money from his friends abroad to the debit of his account in extraordinary cases. Whatever Molnár's monograph writers say, this relationship was a loving alliance of two people who belonged to each other right up to Molnár's death. Darvas' sympathy was clearly manifest in the fact that she allocated the royalties that were due her from Molnár to his daughter and grandchildren.

In the thirties, Molnár disguised his absence from Hungary as a series of trips dedicated to productions abroad or as vacations, though this absence was more and more a matter of compulsion. He also felt an increasing aversion towards his "native village" Pest. As early as the beginning of the twenties, right after the revolutions and the Trianon Peace Treaty, the political atmosphere of Budapest had changed. Many of his friends had either emigrated or lived far away from the country as foreign correspondents. In the meantime, Molnár was envied for his tremendous success and the prosperity that went with it by more and more people at home. The reviews he received had become increasingly hostile. The use of abusive language about Jews had become more and more common in Budapest. Through his secretary, this atmosphere was reflected in his memoirs in the following way: "She knew she would be the traveling-companion of a man whom the new, hateful, Central European tide had wounded to the heart and made shy on human contacts." ${ }^{\text {61 }}$ In spite of the great triumphs, he looked at the years of his European exile as the "unhappy twilight of my career". ${ }^{2}$ One could argue that Molnár became an émigré not in 1940, but much earlier, after the collapse of the Monarchy and the failures of the 1918 and 1919 revolutions. The first and decisive shock for him had come with the disappearance of liberal Hungary. He began to feel as if he were a visitor in his home country. The rise of Hitler, the tragic swing to the right in Hungarian politics, and the country's commitment to Hitler's Germany only reinforced his absence and made it definitive. His emigration followed essentially the same pattern as that of Hungarian scientists. First he left for Europe and from there for America. ${ }^{63}$

The homeless writer - whose real home was Budapest and the Monarchy - established himself in new surroundings, in the public places of Venice, Geneva, and Paris: the hotels, foyers, restaurants, cafés and their terraces, small pubs, and sometimes embassies where émigré writers and intellectuals met. As he con- 
fessed, he spent a considerable amount of time at railroad stations watching the passengers. Abroad he consciously maintained relations out of pure self interest with Hungarian diplomats, acquaintances who had become influential, native Italians and French, people from the world of the theater, and even the prefect of the Parisian police. He also cultivated ties with his circle of friends back home from both the world of the theater and that of journalism by writing letters continuously to many of them. He may have lived on the French Riviera or in Italy, but he still knew everything about the events going on in the field of the theater and the press at home. His measure of success was the premieres in Hungary, and the weathervane of his achievements was his connections back home. ${ }^{64}$ His closest friend was Andor Miklós, the proprietor and leader of the largest Hungarian newspaper, publishing and printing concern, the Athenaeum Literary and Printing House Company. With Andor Miklós's early death in 1933, a strong link tying Molnár to the Hungarian capital and its mobile intellectual and business elite was broken. The leading journalists of Andor Miklós's papers also belonged to the circle of his closest friends.

\section{Last Time in Hungary}

The last time Molnár visited Hungary was on the occasion of the premiere of Delila in September, 1937. He did not face any obstacles in his visits to Hungary, even towards the end of the thirties, but after the passage of the so-called First Anti-Jewish Act ${ }^{65}$ he became increasingly sure that he would not visit his home for a long time to come. ${ }^{66}$ It was the task of the radical right-wing press chamber created by the act to drive Jews out of theaters and journalism. The organization did not register anyone automatically, and as Molnár was abroad he did not ask to be registered either. As a result, he could no longer publish in Hungary. It is absurd that when Molnár stepped onto American soil he was no longer welcome back home as a Jewish writer and journalist. Still, Molnár had on him an invitation from Hungary's Regent, Miklós Horthy, and his wife to attend the state celebration in commemoration of the 500th anniversary of King Mathias's birth. Molnár, the bitter émigré, was invited to the banquet on February 24, 1940, as the 1935 recipient of the Corvin Wreath, one of the highest government awards for cultural and scientific achievements in interwar Hungary. The writer still figured on the address list of the Regent's chef de cabinet, ${ }^{67}$ in a country, allied to Nazi Germany, in which anti-Semitic laws were already in force.

In May 1938, following the Anschluss, he immediately lost all the possessions and deposits he had kept at the Hotel Imperial in Vienna. His personal property in 
Hungary was preserved in the warehouse of the Budapest branch of the American Vacuum Cleaner company. In the spring of 1940, following an appeal, he had his villa in Buda (which, despite his tremendous successes, was hardly extravagant) registered in his daughter's name. With the assistance of attorneys and friends, he providently secured his bank account in New York. His contract with the bank made it possible for him to keep his wealth even as a citizen of a potentially belligerent enemy country.

His final departure went practically unnoticed in Hungary. The public had been accustomed to his living abroad, and in those days more and more people opted to leave their homeland behind. Amidst the great wave of emigration it did not strike anyone that Molnár had left for good. One peculiar literary commemoration was dedicated to him. The literary monthly, Szép Szó (Fine Words), which published all shades of left-wing ideology except communist ideas, bid good-bye to Molnár in the form of an obituary notice, though of course he was still alive. The title of the play was "A Vision of Departed Writers", ${ }^{68}$ and it memorialized two writers who had died around the time. The word "departed", however, has the same double meaning in Hungarian as in English. In relation to Molnár, the writer uses the word in a symbolic sense. It is about the rupture between Molnár and his audience, putting into words the pain the writer feels when he is cut off from his readers, who are his spiritual relatives. The article characterizes Molnár as "a prince exiled with an internal Nansen passport," who lives "in the citizenship of fast trains," but who sends his new books

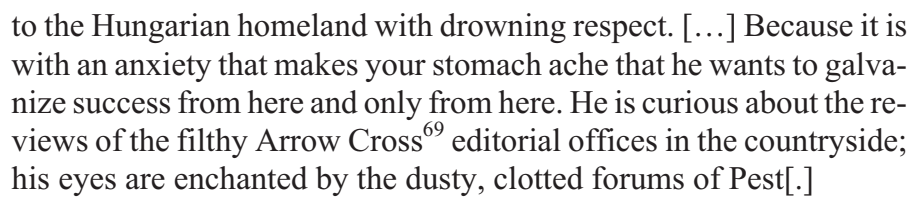

The writer, the author says, is undeniably Hungarian. All that is remembered about him and what is rumored about him at home, "his haughtiness and relentlessly mischievous distrust", are sheer masks in order to disguise his bitterness, namely, that he knew that he would never become a tranquil, old pensioner living out his last days in the country of his birth.

Molnár showed the rapid changes and the criticism of the beginning of the 20th century, the "Hungarian changes", which were already "stale [and] addled" at the moment of their conception. They were desired and disliked, and Molnár was also immersed in and perhaps even depraved by them. Still, as the essay highlights, masterpieces such as his short novel The Captain of St. Margaret's took shape in this milieu. ${ }^{70}$ 


\section{Opportunities Offered by New York}

There is only indirect information concerning Molnár's recollections of his visit to America in the twenties. Most probably, however, they were quite pleasant. When Darvas made up her mind to leave Europe and move to New York for good, Molnár definitely encouraged her: "As regards America, my sure instinct is that once you set foot in New York, you will breathe fresh air, full of ambition and possibilities, and you are bound to be refreshed! [...] You will land in a different world, where free and wealthy people think exactly like you and where general tenderness and care will await you. This is not solely my speculation, this is what I keep reading in the papers, and this is what two Hungarians who recently arrived from [America] told me the other day. The greatest satisfaction and recreation will await you there, and you will forget this damned Europe in a day." Overlooking the didactic tone of these sentences, the voice seems sincere. In addition, a few paragraphs later, Molnár reinforces it all with self-irony: "There is no reason to wither, and it is me telling you this, the sixty-year-old ancient Jew! [...] go where there is fresh air and rebirth, and the possibility of new struggle and new success is itself refreshing." ${ }^{, 11} \mathrm{He}$ also offered her serious advice on many occasions: she should beware of the media, especially of Hungarian emigrants; she should keep emphasizing that it is only an excursion abroad so that her potential rivals will not become jealous of her, at least not initially. It seems conceivable that he was also encouraging himself in these letters, though the available data do not suggest that he was seriously preparing to emigrate at the time. Even in November, he writes about traveling to America as something that requires a serious decision. What enticed him to contemplate emigration is rather the fact that in Paris, in November 1938, despite all the assistance, the "greatest connections" at his disposal, there were 500,000 "rivals", that is refugees, making it more difficult for him to obtain an extended residency permit. When in spite of this he finally received a one-year French visa that guaranteed multiple entries, he escaped from the irritating Parisian atmosphere to San Remo. Undefined Hollywood invitations reached him there as well. Still, contemplating a future extension of his French visa, he asked his wife to have thirteen copies of the American deluxe edition of his plays sent to his friends at his expense as soon as possible. The American offers kept coming, including the telegram from David O. Selznick in April 1939 that is mentioned as the fourth in his letters. ${ }^{72}$ In the letter in which Molnár informs Darvas of Selznick's invitation, he already tells her briefly that he has an American visa and urgently requests the invitations promised by Columbia University through her. ${ }^{73}$ He would have liked to have been asked to give lectures on literature by the fall of 1939. Even if the lectures were largely a pretext, they served as an official reason for the decision and facilitated his entry into the United States. 
Molnár arrived in New York alone. His secretary, proofreader, and nurse for the next seven years, Wanda Bartha, followed him in May 1940. She lived separately on the 11th floor of the Plaza Hotel in a tiny room. After her death, Molnár confided that it was thanks to Wanda that he painlessly managed to cut the bonds between himself and mankind. The previous years spent together and the European trips created a dream world around him that "was a hypnotic trance," and in the meantime he did not want to become aware of what was taking place in Europe. This statement should be read with some skepticism, however. According to his letters to his wife, he knew what was going on, and he might only have distanced himself from terror as a form of self-defense, just before the final catastrophe. He was no doubt at home in Europe until the very last minute, aware of its cultural scene, the human and national gestures. Everything had changed in the United States. The secure ground of Europe had vanished from beneath his feet.

Right after the war, upon the request of a certain "Mr. North" [possibly Alex], Molnár summarized in a relatively long and witty letter the differences between staging a play in Europe and in America. One can interpret this incidental letter as the confession of the European theater. The reason for the differences, according to Molnár, is not intellectual but merely financial, and it resides in the fact that "here far more people interfere with the author's work than over there [...] The old and indestructible belief of people with money is that the more people are involved in writing a play, the more successful it will be." ${ }^{, 74}$ In sixteen points, he lists the different people who have their say in a performance on Broadway: automatically there is an assistant writer at the side of the playwright, then there is the director, the producer, a gagman guest, the male and female stars, an unknown gentleman, by virtue of being the agent of a certain somebody, probably even an elderly lady arguing for the particular requirements of morning performances, and the wives and sons-in-law and secretaries of each member of the crew. Eventually, this machinery suffocates originality, and the author, seeing what has become of his play, weeps silently during rehearsals in the last row of the first circle. In Europe, where productions are done with far less money, theater people can afford to venture working even with an original writer whose work the crowd might dislike. Molnár suggests that something innovative will probably come from $\mathrm{Eu}-$ ropean theaters with lower budgets, because this makes them more adventurous. Finally, he enumerates his favorite American playwrights in alphabetical order. The list proves his enthusiasm and thorough knowledge of contemporary American theater: Samuel Behrman, Ben Hecht, Sidney Howard, Eugene O'Neill, Sampson Raphaelson, Elmer Rice, William Saroyan, Robert Sherwood, and Thornton Wilder. ${ }^{75}$ 


\section{Emigration as a Disease}

Molnár was working continuously, but he wrote barely anything new. The wheels of the mill were spinning, but they were not grinding anything. What he wrote was affected and sentimental. ${ }^{76}$ He worked for the film industry, but no information is available concerning the outcome of the projects. It was rumored that Chaplin, whom he knew from Salzburg through Max Reinhardt, ${ }^{77}$ would play the main role in his play ... or not to be, written in Geneva. The play does exist, and there is one copy of it in the New York and one in the Budapest Molnár papers. Nevertheless, the rumor concerning Chaplin proved false.

However, a great success was to come, even if Molnár himself was not an active participant in it. What George Gershwin could not achieve, Richard Rogers and Oscar Hammerstein could. Until then, they had had only one success, which was later followed by many other phenomenal triumphs. ${ }^{78}$ They had the possibility to write a musical - in Molnár's interpretation an "opera-like music play" based on Liliom, with the title Carousel. Molnár compared the result to Carmen and La Bohème. The premiere was on April 19, 1945 (the war in Europe had not yet ended). The story's setting (originally the neighborhood of a city park in fin-de-siècle Budapest) was converted into a small American town by the sea in the state of Maine. What is more significant, however, is the altered ending. In the original play there is no salvation, whereas in this version there is. The play was met with enthusiastic acclaim and remained on the program in New York's Majestic Theater for two years, going through 890 performances. According to Richard Rodgers's diary, Molnár happened to appreciate the ending especially. The two authors remained grateful to Molnár for their success. In 1951, in a warm-hearted offer, they asked Columbia University to award Molnár the same honor that they had received for Carousel. ${ }^{79}$

Molnár learned after the posh and jolly premiere that his son-in-law György Sárközi had died of malnutrition in a forced labor camp in the city of Balf in Western Hungary. Sárközi, whom Molnár had presumably met no more than once or twice, was a respected figure in Hungarian literature. He had served as the literary manager of Athenaeum Publishers (in which by the way Molnár's old friend, Andor Miklós had some interest), and was also a translator, poet, novelist and

journal editor. Molnár commented on his death to his widowed daughter much later.

Márta Sárközi, Molnár's daughter and the mother of three children, summoned the crème de la crème of Hungarian literature to the terrace of the bombed-out villa she had received from his father, where she resurrected Válasz, the best literary journal of the brief era of barely four years (1945-1948) of a democratic multi-party system in Hungary. György Sárközi had been the editor of the journal when it had been in publication between 1934 and 1938. Thus, the young widow 
continued what her husband had begun. Márta Sárközi spent all the money that she received from her father on the periodical, which represents one of the intellectual and moral treasures of the 20th century. ${ }^{80}$

The relationship between father and daughter was one-sided in nature. It had always been like that, since the husband and his wife, Molnár and Margit Vészi, had separated before the birth of their daughter. Márta Sárközi managed her father's business at home and sent reports concerning the events, but with a few exceptions her reports and letters went unanswered. ${ }^{81}$ Molnár's valuables, which were kept in storage, were first confiscated by the so-called "Commission for Abandoned Valuables," but were later returned, but it is not clear whether anything had been stolen. Nonetheless, the library that remained represented a serious problem. The flats of relatives and friends had been damaged during the bombing raids, and they could not accept the books. Several things were of vital necessity in Budapest after the siege of the city, but books were not among them. Molnár's daughter offered them along with her husband's books to Eötvös Collegium, an elite educational institute founded in 1895 on the model of the French École Normale Supérieur. The collections were thus transferred to an excellent institution. Later, Molnár stopped sending anything to his daughter when he learned from a letter from one of his friends that she was publishing works by Fascist writers in her journal as well. The accusation was nonsense, of course, though Sárközi did facilitate the return of writers who had been found guilty of right-wing sympathies during the general ideological chaos of the Second World War. Nevertheless, Molnár took the news literally and severed all his ties with his daughter and her family for good.

Molnár led a safely well-to-do life thanks to the royalties that continued to arrive. None of his works touches on contemporary politics or refers to the events in Europe and his home country. War might seem to have left Molnár unaffected despite the fact that, even as an emigrant, he was aware of everything. He was not entirely unsympathetic, for he supported many friends and relatives, among them his sister and daughter, sending them money, medicine and nylon stockings, items particularly easy to sell for good money in Hungary. One of the people he supported was his long-time friend, the book designer Elek Falus. The letters he sent to Molnár on his illness, his destitution and the current state of affairs in Hungary were not lost, and thanks to Darvas they became part of a public collection. ${ }^{82}$ Molnár supported Dániel Jób as well, the ex-director and manager of Vigszínház, who found himself in a state of disastrous poverty. Although he had regained the leadership of the theater, Jób had been removed two years later for political reasons.

In New York, Molnár received invitations from the elites of the art world on a regular basis, both immediately upon his arrival and during and after the war. He had Max Reinhardt as a steady liaison, but Reinhardt died unexpectedly in 1943. 
The playwright George Middleton, chairman of the American Stage Writers' Association, was among his acquaintances. In fact he was Molnár's longest-standing American connection. Sam Jaffe was a regular guest and an occasional assistant. Molnár had a good relationship with the critic George Freedley, the curator of the New York Public Library's theatrical collection, the actress Ruth Gordon, and the entrepreneur Morris Gest, who happened to be David Belasco's son-in-law, as well as several leaders of the Metropolitan Opera. The owner of the Astor Hotel, Fred Muschenheim, was also among his friends. Molnár knew him from Europe, and there was always a colorful and intriguing company gathering at his place, including Vladimir Horowitz, Bruno Walter, John Barbirolli, Fritz Kreisler, Erika Mann and many other recurrent guests. While Molnár had many social acquaintances, he had few close friends. Molnár and Wanda Bartha would lunch together with Darvas regularly, sometimes together with Edward G. Robinson. Molnár sometimes met Sir Alexander Korda, who occasionally visited the United States. He was the owner of London Film Productions and a world-famous Hungarian film director whom Molnár had known in Hungary, though he remembered little more than how incredibly rich and nonetheless humble he was.

If the characters in Molnár's Companion in Exile are meticulously enumerated, the only thing that finally remains is the list of people with whom Molnár had come into contact. Though the list is formidable, Wanda Bartha's diary, the basis of the book, is little more than an inventory. Enumeration itself does not convey the nature, depth, sincerity, or, at times insincerity, of these relationships. It does not contain a single line of Molnár's reflections. In addition, there is little indication of Molnár's personal opinion of these people. One can hardly blame Wanda Bartha for these shortcomings, since she took these notes of celebrities and events for herself with the intention of writing about them to her siblings and friends. Wanda Bartha's enthusiasm for celebrity often proves a bit unsettling in its naivety. She was thrilled, for instance, to catch a glimpse of Greta Garbo from a distance. $^{83}$

Bartha's suicide in 1947 was a complete shock to Molnár. He found himself completely alone. Instead of examining his conscience and realizing how he had treated her, however, he merely felt sobbing pity for himself at the loss of his secretary. He devoted a separate chapter to self-pity in Companion in Exile. The descriptions of his noble sentiments can be read as dubious excuses. Psychology terms this phenomenon sublimation: through the loss of Wanda Bartha, Molnár was confronted with his own callousness and insults, gestures of which he had been unaware at the time and for which he no longer had any opportunity to offer any atonement.

At the same time, Molnár's additions to Wanda Bartha's notes reflect the sorrowful ending of a truly glamorous life. A separate "short story" depicts the city block in which he lived with his secretary. It is about the everyday settings of an 
ordinary life including shops, restaurants, cafés, pharmacies and the waiters, tailors and shop assistants in these places. "This is a rough cross-section of our New York 'social life,' which went on among simple, quiet people, the way we liked it to be[.]" ${ }^{84}$ Molnár lived in noisy loneliness. He was truly alone, especially after Wanda Bartha's death. The only person who remained with him was Darvas, living a few blocks away.

In a tragic work written in New York City Molnár describes emigration as a disease. ${ }^{85}$ This text from 1946 constitutes a literary description of emigration and a personal confession. As long as one is a tourist, one can lead a normal life in the city. But as the years pass by, Molnár slowly becomes an immigrant. First his acquaintances detect the symptoms: "his nerves are more difficult to govern, his complaints are numerous but trivial, his talent for criticism rapidly develops, his desire to contact his natives diminishes constantly, and his English gets worse and worse because his mind gave up the futile fight of an aged person attempting to acquire the skills of a foreign language." The first warning for the émigré comes when he realizes that he cannot sleep without pills. Some of them reach this stage more quickly, some of them not:

\begin{abstract}
It is quicker in the case of a solitary person. For those who have families, it is slower. For the wealthy, it is also slower. But for the poor, it is not. Children are not infected: emigration is not an infantile disease. It is the disease of the so-called withering aged men. [...] One remains oneself more and more, while around one everything is beginning to appear different from what it seemed to be.
\end{abstract}

The emigrant does not get used to his circumstances or the foreign country, but to his own state. And that is the second phase of the disease. This stage is already detectable by an electrocardiogram, and the doctor prescribes injections and capsules. And what can you do when you are fed up with powerless doctors? Molnár regarded the friendship of Göndör as the only effective medicine. Göndör was an outstanding central figure among leftist liberal Hungarian emigrants in New York and the editor of $A z$ Ember [The Man], a journal of émigrés published in Hungarian. ${ }^{86}$ His special treatment lies in his attention and the fact that he recognizes the existence of the émigré. Göndör often calls, makes friendly inquiries, and conveys soothing messages. He invites him to his place and makes peace between him and other émigrés. But Molnár summarized all this in a prosaic address. The writing centers only on how Göndör's method worked in the cases of others. None of it helped him personally.

For Molnár, who was an international author enveloped in the Hungarian language and culture, emigration represented a period of gradual demise. His works and his private life follow two radically different paths. 


\section{Notes}

1 There are two Hungarian language monographs on Ferenc Molnár: Sárközi, Mátyás (1995)

Színház az egész világ (All the World is a Stage) (Budapest: Osiris - Századvég,); and Csordás, Lajos (2004) Molnár Ferenc (Budapest: Elektra Kiadóház); for English language monographs see Györgyey, Clara (1980) Ferenc Molnár (Boston: Twayne Publishers); Kövary, Georg (1984) Der dramatiker Franz Molnár (Innsbruck: Universitätsverlag Wagner). There is a shorter biography and bibliography by Veres, András (1999) 'Ferenc Molnár', in Steven Serafin (ed.) Twentieth-Century Eastern European Writers. Dictionary of Literary Biography, Vol. 215 (Detroit-San Francisco-London-Woolbridge: The Gale Group, A Bruccoli Clark Layman Book). 250-261.

2 Gilbert Miller (1884-1970), producer, director, theatre owner, performer and writer. He produced seven Molnár plays in New York, five before Molnár's emigration. His connection to Molnár began in the theatrical season of 1920/21, when he came to Budapest to see The Swan. Interestingly, that season the Vigszinház (Merry Theater) was purchased by an American entrepreneur, Ben Blumenthal. From then on, the theater functioned primarily according to business considerations. Supposedly, this change of proprietors had contributed to the fact that American producers had taken more interest in the theatrical life of Budapest.

3 Chaim Weizmann (Russia, 1874-Israel, 1952), scientist (chemist), president of the World Zionist Organization (WZO) and first President of the State of Israel (1949).

4 Molnár, Ferenc (1951) Companion in Exile. Notes for an Autobiography by Ferenc Molnár. Translated by Barrows Mussey (London: W. H. Allen). 213. The original manuscript can be found in The New York Public Library.

5 Michael Todd (Minneapolis, MN, 1909-Grants, NM, 1958), Broadway and film producer. Todd was one of the contributors to technical innovation (big screen and sound system) in the film industry of the 1950s. He was the producer of the Broadway musical and later the film Around the World in Eighty Days (1946 and 1956 respectively). The film was awarded an Oscar.

6 Molnár, Ferenc (1951) Companion in Exile. Notes for an Autobiography by Ferenc Molnár. Translated by Barrows Mussey (London: W. H. Allen). 214.

7 Max Reinhardt (Baden bei Wien, 1873-New York, NY, 1943), an influential Austro-Hungarian, then American theater and film director and actor. See Carter, Huntly (1914 repr. 1964) The Theatre of Max Reinhardt (New York: Benjamin Blom); Jacobs, Margaret and Warren, John (eds) (1986) Max Reinhardt: The Oxford Symposium (Oxford: Oxford Polytechnic).

8 The characters in the play are actors. When the main character learns that Napoleon has had his son executed, he confesses to his actor friends that he is unable to face the pain he feels because unlike most people he has acted out pain on stage so many times: "I am unable to face real tragedy because I have faced the pretended and learned one so many times. I don't know what to do [...] so that it would not be acting. [...] What a dreadful punishment this is for having feigned suffering on stage!"

9 Vörös, Károly (1978) "Pest-Budától Budapestig", in Budapest története a márciusi forradalomtól az öszirózsás forradalomig. Budapest története IV (The history of Budapest from the Revolution of 1848 to the Revolution of 1918) (Budapest: Akadémiai Kiadó). 117-320.

10 Lóránt Czigány, A Pseudo-Victorian Era. In: Lóránt Czigány, A History of Hungarian Literature. From the Earliest Times to the Mid-1970s (Oxford: Clarendon Press, 1984). 247-262.

11 At the time, Budapest was bigger than Amsterdam, Lisbon, Hamburg, Brussels, or Naples.

12 Max Nordau (Pest, Hungary, 1849-Paris, France, 1923), physician, writer, social critic and Zionist leader. 
13 Still part of the Austro-Hungarian Monarchy, Hungary had introduced the comprehensive regulation of travel with documents for the first time in 1903 because of massive emigration to the United States. Prior to this date official travel documents were required only for journeys to the East, namely, to Serbia, Romania, Russia and Turkey. See Bencsik, Péter (2005) A magyar úti okmányok története 1867-1945 (The History of Hungarian Travel Documents, 1867-1945) (Budapest: Tipico Design). On free traveling in the "good old days" see Polanyi, Michael (1944) 'The Socialist Error', The Spectator, March 31, 1944, quoted by Tibor Frank, Cohorting, Networking, Bonding: Polanyi, Michael (2001) 'Exile', Polanyiana. The Periodical of the Michael Polanyi Liberal Philosophical Association. Vol. 10, Number 1-2, 108. The famous Austrian writer Stefan Zweig was a member of this generation and a contemporary of Molnár. Zweig emphasized his European-ness in the subtitle of his well-known memoirs: Zweig, Stefan (1944) Die Welt von Gestern. Erinnerungen eines Europäers (Stockholm: Bermann-Fischer Verlag), (1943) The World of Yesterday: Memories of a European (London: Cassel).

14 The law was passed by the incoming Horthy-regime in 1920. It introduced a population-based quota system in higher education. For the text of the act see 1920. évi XXV. tc. Magyar törvénytár: 1920. évi törvénycikkek (Hungarian Collection of Laws: The Acts of 1920) (Budapest: Franklin, 1921). 145-146.

15 József Vészi (Arad, Austro-Hungarian Monarchy, 1858-Budapest, 1940), journalist, editor, one of the most influential press magnates of his era. He was the editor-in-chief of the German language daily Pester Lloyd for decades.

16 Margit Vészi (1885-1961) was Molnár's first wife for quite a short time. She herself was a writer, painter, and participated in the group exhibitions at the beginning of the century. Actually, she was one of the first Hungarian female journalists. The war reports that she published during the years of World War I were even compiled into a separate volume. Having divorced Molnár, she married an Italian baron. She too decided to leave Hungary in the 1920s and, eventually, also ended up in Hollywood, where she worked as a scriptwriter for a few years. She returned to Europe and finally committed suicide.

17 Oszkár Jászi (Nagykároly, Hungary, 1875-Oberlin, OH, 1957), sociologist, university professor, and politician opposed to the system of large estates, clericalism and the repression of nationalities. In 1914, he founded the Civil Radical Party. In 1919, he left Hungary. He settled in the U.S. in 1925.

18 The government of Mihály Károlyi was in office between October 31, 1918 and January 19, 1919.

19 As is written on the inside cover of the book: "This volume [...] is published simultaneously in the languages of their countries, in Budapest, Berlin, Rome, London and New York." Molnár, Ferenc (1929) The Plays of Ferenc Molnár. Foreword by David Belasco (New York: Macy-Maasius, The Vanguard Press).

20 Quoted by Louis Rittenberg. In: The Plays of Ferenc Molnár, XV.

21 Ermete Zacconi (1857-1948), Italian theater and film actor, director, representative of the "verist" trend on stage. He played the role of the main character in Molnár's play The Devil for thirty years.

22 Ferenc, Molnár (1962) 'Vasárnapi krónikák. Három kis eset' (Sunday Chronicles. Three Little Cases), in Ferenc Molnár Szülöfalum, Pest (My Native Village, Pest) (Budapest: Szépirodalmi Könyvkiadó) 537-539. It is important to underline that literary scholarship and theater-research started to deal with the system of intercultural relationships much later. As of today, this area of studies is first and foremost dealt with by Patrice Pavis, the professor of Université de Paris VIII (Vincennes - Saint Denis). As visiting professor at Indiana University, Bloomington, Pavis gave courses on the problems involved in the translation of works for the theater. 
23 The theatrical copies of the translations can be found in the Collection of the History of Theater at the National Széchényi Library in Budapest. For the literature on Molnár's translations see Molnár Gál, Péter (1993) 'Molnár Ferenc, a fordító' (Ferenc Molnár, the Translator), Színház, Vol. XXVI, No. 1, 40-48; and Szilágyi, Ágnes (1996) 'Molnár Ferenc francia bohózatfordításairól' (On Ferenc Molnár's Translations of French Farces), in Ferenc Glatz (ed.) Magyar iró és világpolgár. Begegnungen. Schriftenreihe des Europa Institutes Budapest, Band 2, 49-54. Molnár also translated into Hungarian Gerhart Hauptmann's drama Fuhrmann Henschel (1898), Anatole France's novel Le lys rouge, and Jerome K. Jerome's play Miss Hobbs (1904). He translated works by Alfred Hennequin, Georges Feydeau, Robert Flers, Gaston Armand de Caillavet, and Ludovic Halévy.

24 Molnár Gál, Péter (1993) 'Molnár Ferenc, a fordító' (Ferenc Molnár the Translator), Színház (Theater) Vol. 1, 40. Note that Péter Molnár Gál has written an extensive monograph on Ferenc Molnár that is forthcoming in Budapest in 2009.

25 The peculiarity of The Devil is that its title-role is the developer of desires and sexuality exiled into the unconscious. In the play, much influenced by the Faust-idea, the propositions of Freudian psychology are supported and confirmed on stage.

26 On Liliom see Kerr, Alfred and Franz Molnár (1917) 'Liliom', Alfred Kerr Gesammelte Schriften. Die Welt in Drama (Berlin: S. Fischer Verlag). 269-272.

27 Szerb, Antal (1934) Magyar irodalomtörténet (The History of Hungarian Literature) (Budapest: Révai Kiadás). 491-493. Molnár's brother-in-law, Lajos Biró, was another export playwright whose career reached its zenith abroad. Lajos Biró was the scriptwriter of successful movies such as "The Private Life of Henry VIII", "Hotel Imperial", and "The Thief of Bagdad". Biró collaborated with London Film Production, the empire of Sir Alexander Korda (also of Hungarian origin), working with the Korda brothers as their equal.

28 For the most authentic treatise of this proposition see Illyés, Gyula (1963) 'Préface' in László Németh Une possédée. Translated by P. E. Régnier, C. Nagy, L. Gara (Paris: Gallimard). 7-20.

29 Molnár, Ferenc (1901) Az éhes város (The Hungry City) (Budapest: Révai); Molnár, Ferenc (1918) Andor (Budapest: Athenaeum).

30 The novel has been translated into more than 40 languages. Two translations have been popular in German: Molnár, Ferenc (1910) Die Jungen der Paulsstrasse. Ein Roman für kleine und grosse Studenten. Translated by Eugen Heinrich Szhmitt (Berlin); and the translation by the same title by Deutsch von Edmund Alkaly. Leipzig - Wien, 1928. For the English version see: Molnár, Ferenc (1927) The Paul Street Boys Translated by Louis Rittenberg (New York, NY: Macy Masius).

31 Molnár, Ferenc (1945) Gözoszlop (The Captain of St. Margaret's) Translated by Barrows Mussey (New York, NY: Duell, Sloan \& Pears).

32 Menyhért Lengyel's (Melchior Lengyel) drama Typhoon resulted in a similar breakthrough in 1909. Lengyel, Melchior (1913) Typhoon (Taifun), Translated by Laurence Irving (London: Methuen). Some of Lajos Biró's plays and some fifteen years later the screenplays based on them met with similar success. It is important to point out though that Mór Jókai, the leading Hungarian novelist of the 19th century, was the first to be published in foreign languages; his works were popular mostly in German, but he had achieved significant successes in English too. See Czigány, Lóránt (1976) A magyar irodalom fogadtatása a viktoriánus Angliában 1830-1914 (The Reception of Hungarian Literature in Victorian England 1830-1914). Irodalomtörténeti Füzetek 89. (Budapest: Akadémiai Kiadó).

33 Schöpflin, Aladár (ed.) (undisclosed date of publishing [1929-1931]) Magyar Színmüvészeti Lexikon. A magyar szinjátszás és drámairodalom enciklopédiája (Lexicon of the Hungarian Art of Drama) (Budapest: Országos Színészegyesület Nyugdíjintézete). Vol. III, 402. 
34 Morrison, William (1999) Broadway Theatres: History and Architecture (New York, NY: Dover Publications).

35 Molnár Rajec, Elizabeth (1986) Ferenc Molnár. Bibliography I-II (Wien-Köln-Graz: Hermann Böhlau).

36 It must have been the Terrace Garden Theater that also produced Hungarian language emigrant acting.

37 Sárközi, Mátyás (1995) Színház az egész világ (All the World Is a Stage) (Budapest: Osiris Századvég). It is important to note that most of the biographies dealing with Molnár are based on anecdotes and humorous stories often impossible to check. They have a common source: during his life, a weekly entitled Szinházi Élet (Theater Life), similar to (or even the Hungarian equivalent of) Vanity Fair, often dedicated attention to Ferenc Molnár. It can also be observed that the essays written on Molnár take for granted what he quotes in his memoirs, Companion in Exile, from his secretary commenting on their life. In this book it was Molnár himself who denied being the author of the witty remarks that were attributed to him. According to him, at least half of them were not his. (See Molnár, Ferenc (1951) Companion in Exile. Notes for an Autobiography by Ferenc Molnár. Translated by Barrows Mussey (London: W. H. Allen). 28-29). Note that a thorough and reliable Ferenc Molnár biography and appraisal is still not available. Also missing is the publication of his correspondence from which the chronology of his travels, experiences, and relationships could be accurately reconstructed. As basic sources, there are two public collections related to Ferenc Molnár. The Petőfi Irodalmi Múzeum (Petőfi Literary Museum, PIM) in Budapest preserves the legacy of Lili Darvas. With this group of documents hundreds of letters were returned to Hungary. The other and bigger collection is to be found in The New York Public Library, more precisely within the Billy Rose Theatre Division. Molnár himself donated these documents in 1947. The Molnár Papers contain a selection of scripts, correspondence and articles written by Molnár between 1927 and 1952. Another important point of reference would be the papers of Edmund Pauker, Molnár's American attorney. See Edmund Pauker Papers. General Collection, Beinecke Rare Book and Manuscript Library, Yale University.

38 Molnár, Ferenc The Devil (1908: American Motoscope \& Biograph Co., 1915: New York Motion Picture, 1921: New York Motion Picture), A Trip to Paradise (See also Liliom, 1921: Metro Pictures), Fine Clothes (1925: Louis B. Mayer Production Inc. - First National Pictures), The Swan (1925: Famous Players Lasky - Paramount Pictures), His Glorious Night (1929: MGM), Prisoners (1929: Walter Marosco Production - First National Pictures), Olimpia (1930: MGM), One Romantic Night (1930: United Artist), The Guardsman (1931: Metro-Goldwyn-Mayer), Liliom (1930: Fox Film Corp., 1934: Fox Films), No Greater Glory (1934: Columbia Pictures Corp.), The Good Fairy (1935: Universal Pictures Corp.), The Bridge Wore Red (1937: MGM), Double Wedding (1937: MGM).

39 Molnár, Ferenc (1937) All the Plays of Molnar (New York: Garden City Publishing Co.). Forward by David Belasco, De luxe edition, 823. The same collection was published as Molnár, Ferenc (1929) The Plays of Ferenc Molnar (New York, NY: Macy Masius, The Vanguard Press). Note that prior to the American edition there had been published a drama anthology of Molnár in London: Molnár, Ferenc (1927) Plays of Molnar Translated and introduction by Benjamin Glazer, (London: Jarrolds).

40 Louis Rittenberg (Tiszaújlak, Hungary, 1892-New York, NY, 1962), journalist and translator. He moved to the United States quite early in 1906. From 1937 on, he was the editor in chief of the American Hebrew, and at the same time the American editor of the London Jewish Chronicle.

41 Advertising was becoming more and more powerful in Europe too. In 1910 the first and most successful Hungarian daily tabloid, Az Est (The Evening), was launched. It had a long-stand- 
ing and successful career and was circulated in hundreds of thousands of copies. At the request of the proprietor chief editor and friend, the advertisement texts were written by Molnár. Despite the fact that advertising was part of Europeans' everyday life, those visiting America were fascinated and also shocked by the sheer mass of American advertisements, their frequency and appearance. The memoirs of the Austrian-Czech tenor, Leo Slezak, are interesting from this point of view. The singer was contracted by the Metropolitan in New York at the time of Molnár's first premiere. Arriving from Europe and the world of the Monarchy, Slezak was taken aback by the appearance of the advertisements accompanying the opera performances. In the leaflet of Othello, for example, the section describing the content of the opera also included framed advertisements for food products. See Slezak, Leo (1934) Meine sämtliche Werke. Der Wortbruch (Berlin: Rohwolt). 30-70.

42 Gajdó, Tamás (ed.) (2001) Magyar szinháztörténet 1873-1920 (The Hungarian History of Theater 1873-1920) (Budapest: Magyar Könyvklub - Országos Színháztörténeti Múzeum és Intézet). 143-173.

43 Edmund Pauker, Molnár's American attorney of Hungarian origin, became his personal friend. He had an office on Broadway.

44 On December 14, 1927, Ferenc Molnár gave a lecture in French at Columbia University. The subject was the topics of contemporary European drama. According to the archives of Columbia University, 393 students attended the lecture. Unfortunately the University does not have the written transcript of the lecture. My thanks for accessing the data related to the University go to archivist Carolyn Smith.

45 Before Molnár arrived in New York, Vanity Fair had published one of his longer works in 12 installments. The magazine had commissioned this writing from Molnár by way of appeasement for having published a specious and insulting article about his previous divorce suit; Molnár's representative and attorney in New York, Pauker, had raised the issue with the magazine on behalf of the author. The actors read from the dialogs of this work. The party was held at the palace of Condée Nast, proprietor of Vanity Fair, at 1040 Park Avenue, on the roof terrace on the 14th floor.

46 The meeting took place on December 27, 1927.

47 Waldau, Roy S. (1972) Vintage Years of the Theatre Guild 1928-1939 (Cleveland-London: The Press of Case Western Reserve University). 249.

48 Rumor has it that the Swedish writer, Selma Lagerlöf, who herself was a Nobel prize winner in 1909 , nominated him. Probably his name was brought up among the potential nominees. See Csordás, Lajos (2004) Molnár Ferenc. Életkép sorozat (Ferenc Molnár. Genre Series) (Budapest: Elektra Kiadóház). 93.

49 On the translations of the play see Nagy, Gabriella Ágnes (2004) 'Molnár Ferenc tengerentúli útja. A Játék a kastélyban fordításai, avagy a színházfordítás kultúrája’ (Ferenc Molnár's Trip to Overseas. Translations of The Play Is the Thing, or the Culture of Theatrical Translations) in Imre Zoltán (ed.) Átvilágitás. A magyar színház európai kontextusban. Recepció és kreativitás. Nyitott kultúra c. sorozat. (Screening. Hungarian Theater in the European Context. Reception and Context. Open Culture Series). Gábor Palló (series ed.) (Budapest: Áron Kiadó). 155-170.

50 Henry Miller (London, Great Britain, 1858-New York, NY, 1926), actor, director, theatrical producer and manager.

51 Veres, András (2007) 'Molnár Ferenc színpada' (The Stage of Ferenc Molnár) in Mihály Szegedy-Maszák and András Veres (eds) A magyar irodalom történetei III. 1920-tól napjainkig (Histories of Hungarian Literature III, from 1920 to date) (Budapest: Gondolat Kiadó). 153. 
52 On the issues related to translating Ferenc Molnár see Schöpflin, Aladár (1937) 'Drámairodalom - Molnár Ferenc' (Drama Literature - Ferenc Molnár) in Aladár Schöpflin A magyar irodalom története a XX. században (The History of Hungarian Literature in the 20th Century) (Budapest: Grill Károly Könyvkiadóvállalata). 157-162.

53 Billy Wilder made a movie from this one-act play in 1961 (One, Two, Three, The Mirisch Corporation).

54 Kőrössi P., József (ed.) (2003) Amerika! Amerika! Magyar írók novellái Amerikáról, az amerikai emberröl és az amerikai magyarokról (America! America! Hungarian Writers' Short Stories about American People and Hungarian Americans) (Budapest: Noran Könyvkiadó). At the time when Molnár's career was just beginning, the great old novelist of the era, Kálmán Mikszáth, came out with a novel, The Noszty Boy's Affair with Mari Tóth. In this play, the father of the female main character, Mihály Tóth, also became a millionaire in America, and it is only because of a death in the family that he returns home. The already mentioned successful author, Melchior Lengyel dedicated a separate volume to his American trip. Lengyel happened to be in New York at the time when Ferenc Molnár's Liliom was produced. The account of the successful premiere gets a separate chapter in his book. See Lengyel, Menyhért (1922) Amerikai napló (American Diary) (Budapest: Athenaeum). 190-196.

55 Schöpflin, Aladár op. cit. 157-158.

56 On the presence of Ferenc Molnár in Germany see L. Nagy, George (1978) Ferenc Molnár's Stücke auf der deutschsprachigen Bühne. (Diss: State University of New York of Albany).

57 Molnár, Ferenc (1951) Companion in Exile. Notes for an Autobiography by Ferenc Molnár. Translated by Barrows Mussey (London: W. H. Allen). 51.

58 His second wife, Sári Fedák (Beregszász, Austro-Hungarian Monarchy, 1879-Budapest, Hungary, 1955), a great actress of the era, did a long tour of the United States in 1921 performing in the Hungarian theaters of America too.

59 Within the parts of the Molnár legacy that actually made it to the Petőfi Literary Museum in Budapest through Darvas, among the messages addressed to Wanda Bartha there is only one writing in which Molnár ends the message by referring to her in the informal. The rest of the messages are short and conclude with the neutral "Sincerely Yours". Upon the secretary's death, Molnár told his doctor Henrik Lax, also one of his best friends, who was the doctor of the Hungarian emigration too, that he felt he had lost his child. Doctor Lax corrected him: "When I told him that my child had died, he said, 'No, it was your mother that died." Molnár, Ferenc (1951) Companion in Exile. Notes for an Autobiography by Ferenc Molnár. Translated by Barrows Mussey (London: W. H. Allen). 49.

60 Molnár, Ferenc (1951) Companion in Exile. Notes for an Autobiography by Ferenc Molnár. Translated by Barrows Mussey (London: W. H. Allen). 51.

61 Molnár, Ferenc (1951) Companion in Exile. Notes for an Autobiography by Ferenc Molnár. Translated by Barrows Mussey (London: W. H. Allen). 48.

62 Molnár, Ferenc (1951) Companion in Exile. Notes for an Autobiography by Ferenc Molnár. Translated by Barrows Mussey (London: W. H. Allen). 51.

63 On this aspect of Hungarian emigration see Frank, Tibor (2009) Double Exile: Migrations of Jewish-Hungarian Professionals through Germany to the United States 1919-1945 (Oxford: Peter Lang).

64 Another author with a similar career, Melchior Lengyel, wrote down in his diary in various places how little he was interested in productions abroad. Lengyel, Menyhért (1987) Életem könyve. Naplók, önéletrajzi töredékek (The Book of My Life. Diaries, Biographical Fragments) (Budapest: Gondolat).

65 The First Anti-Jewish Act was passed by the House of Representatives on May 12, 1938, and by the Upper House on May 24. For the text of the act see 1938. évi XV. tc. Magyar 
törvénytár: 1938. évi törvénycikkek (Hungarian Collection of Laws: The Acts of 1938) (Budapest: Franklin Társulat, 1939). 132-144.

66 To illustrate how hopeful Molnár still was in the first months of 1938 or how naively he looked into the future, let us refer to a letter in which Molnár was happy to tell her wife about the news that the ex-Prime Minister, Count István Bethlen, gave a major speech at one of the committee meetings in Parliament on February 9, 1938, which was like an emergency cry to "true Hungarians". Bethlen was opposed to solving the Jewish issue following to the German pattern and to adjusting domestic politics to suit German requirements. Bethlen distanced himself from the extreme right in vain. The political climate had already changed irreversibly. Molnár, Ferenc (2003) “... or not to be”. Molnár Ferenc levelei Darvas Lilihez (“... or not to be". The Letters of Ferenc Molnár to Lili Darvas) (Budapest: Argumentum Kiadó - Petőfi Irodalmi Múzeum). 28. Also see Frank, Tibor (ed.) (2003) Discussing Hitler. Advisers of U.S. Diplomacy in Central Europe 1934-1941 (Budapest - New York: CEU Press). 47.

67 Manuscript division of the Petőfi Literary Museum (PIM), V. 4326/41.

68 Erdős, Jenő (1939) 'Sirató sorok. Látomás eltávozott írókról' (Mourning Lines. A Vision of Departed Writers). Szép Szó, Vol. VIII, No. 31, 4-10.

69 The arrow-cross men were members of a "Hungaricist", extreme right, anti-Semitic movement born in the second half of the 1930s. In October 1944, they took over power in Hungary.

70 Jenő Erdős, op. cit., 7-9; also see footnote 31 above.

71 Letter of Ferenc Molnár to Lili Darvas, March 26, 1938. Molnár, Ferenc (2003) “... or not to be”. Molnár Ferenc levelei Darvas Lilihez (“... or not to be”. The Letters of Ferenc Molnár to Lili Darvas) (Budapest: Argumentum Kiadó - Petőfi Irodalmi Múzeum). 27-29. For a detailed review of the Hungarian volume see Sárközi, Mátyás (2007) 'The Plays and the Wives', Katalin Varga and Tamás Gajdó (eds) The New Hungarian Quarterly, Vol. XLVIII, No. 188. $122-129$

72 It was in this very year that David Selznick made his world-famous film legend, Gone with the Wind, winning an Oscar in the "best picture" category.

73 The invitations were initiated not by the Americans but by the émigré Sándor Incze (1889-1966). Incze was the editor of the weekly entitled Szinházi Élet (Theater Life) between 1910 and 1938. The paper was abolished as a result of the Anti-Jewish Act. In 1939, Incze migrated to New York, where he founded and edited two English language papers, the Stage and the Theater Arts.

74 Manuscript division of PIM, V. 4326/286.

75 The addressee of the letter could not be identified. For the Hungarian and English versions see the manuscript division of PIM, V. 4326/286. The curiosity of the typed and manually corrected Hungarian letter is that some phrases were originally dictated in English by Molnár.

76 Molnár, Ferenc (1945) Farewell My Heart (New York: Simon).

77 The descendants of Ferenc Molnár preserve a fifty-second silent film in which Max Reinhardt, Charlie Chaplin, Paul Robeson, Lili Darvas and Ferenc Molnár “play” Alexander Dumas's work, Dame aux camélias. This is the only picture in the Molnár photographic archive where the man who has made so many laugh is laughing himself, too.

78 Their first success was the musical Oklahoma! (1943); from their later works let us mention South Pacific (1949) and The Sound of Music (1959).

79 Manuscript division of PIM, V. 4326/254.

80 On Márta Sárközi see Széchenyi, Ágnes (2004) 'Műstoppoló és mecénás' (Fine-darner and Patron of Art) in Ágnes Széchenyi (ed.) Menedékház. Sárközi Márta emlékkönyv (Refuge. A Book in Honor of Márta Sárközi) (Budapest: Magvető Kiadó). 11-74.

81 Manuscript division of PIM, V. 4326/95. 
82 Elek Falus (Orosháza, Hungary, 1880-Budapest, Hungary, 1950), graphic artist, industrial artist, and stage-designer. He designed the cover of Typhoon, the play by Melchior Lengyel mentioned above. See Manuscript division of PIM, V. 4326/197.

83 “Yesterday I saw Greta Garbo again at Dr. László's. I don't know how many times I’ve seen her. GRETA GARBO! I keep wishing I could see her over and over again." Molnár, Ferenc (1951) Companion in Exile. Notes for an Autobiography by Ferenc Molnár. Translated by Barrows Mussey (London: W. H. Allen). 266.

84 Molnár, Ferenc (1951) Companion in Exile. Notes for an Autobiography by Ferenc Molnár. Translated by Barrows Mussey (London: W. H. Allen). 290.

85 Molnár, Ferenc (1962) Szülőfalum, Pest (My Native Village, Pest) (Budapest: Szépirodalmi Könyvkiadó). 584-587.

86 Ferenc Göndör (Kaposvár, Hungary, 1885-New York, NY, 1954), journalist. He was a war correspondent in the First World War. In 1919, he escaped to Austria, and in 1926, he settled down in the U.S. It was during the time of the bourgeois democratic revolution in 1918 that he founded his paper entitled Az Ember (The Man), which he carried on in Vienna and New York with identical titles up to 1952 . 
